tisfactory reclamation plan. When this plan is submitted, a permanent permit will be granted. At present the legislation applies only to surface mines although provision is made to extend it, by Order in Council, to any mining operation in the Province.

The legislation is attacked because the responsibility for its administration has been given to the Department of Mines and Petroleum Resources which has assigned specific responsibility for reclamation to only one man, with the rank of Inspector of Mines. The conservation groups want a reclamation division in one of the other natural resource agencies such as exists in Kentucky. Certainly, a larger staff might be desirable to co-ordinate the research which must be carried out and to reduce any duplication of effort, but, unlike the situation in Appalachia, mining has been on a relatively small scale, and there is no great backlog of derelict land that requires such an investment. Personally, I am quite satisfied with the arrangement in British Columbia because many of our reclamation problems are of an engineering nature and can best be overseen by mining engineers, with advice on revegetation coming from other government departments. While in the United States one of the major objections to control of reclamation by a mining inspectorate has been fear of political influence exercised by industry, the personnel of the Mines Department in British Columbia, reflecting British Commonwealth traditions of government, are professional civil servants who are not directly exposed to personal political pressures. I consider that the inter-departmental committee and the availability of the reports to members of the public provide adequate safeguards against the mis-use of discretionary power.

\section{References}

1. MINES REGULATION ACT: STATUTES OF BRITISH COLUMBIA. 1967. Chap. 25. / 1969. Chap. 18, sect. 11. / COAL MINES REGULATION ACT: STATUTES OF BRITISH COLUMBIA. 1969. Chap. 3, sect. 8.

2. HEDLIN MENZIES AND ASSOCIATES LTD., VANCOUVER, B.C. 1969. The impact of the coal mining operations of Kaiser Resources Ltd. on the Canadian economy. Report prepared for Kaiser Resources Ltd. 97 p.
Despite the apparent inferiority of the legislation to some of the Appalachian statutes, it provides a very practical framework for the very different institutional and environmental conditions found in British Columbia. The actual implementation of the legislation is the subject of a detailed discussion in a paper by Thirgood (6). The first temporary permit was only issued in January, 1970, and so we must wait to see how effective the control will be. The really critical time will come when these temporary permits expire in another year. Certainly, if the public desires reclamation, it would be advisable to continually express this desire so that the initial impetus is not lost, but British Columbians are, at least, lucky that they have the chance to prevent rather than repair environmental damage.

I have pointed out some of the social, economic and political factors which must be considered when assessing the requirements for reclamation in any area and, in doing so, I hope that I have shown how much these factors may vary from place to place. We should not reclaim merely for the sake of reclaiming: as foresters, we must recognize the wider responsibilities of our profession.

\section{Acknowledgements}

The author wishes to thank members of the Faculties of Forestry and Law at the University of British Columbia and of the Provincial Department of Mines and Petroleum Resources for helpful discussion. This paper was written as part of a study for a Master's degree on the interactions of the mining industry with other natural resource interests in British Columbia. The financial assistance of the Faculty of Forestry of the University of British Columbia is gratefully acknowledged.

3. KENTUCKY REVISED STATUTES. 1966. Chap. 350.

4. FRANK, R. M. 1964. A guide for screen and cover planting of trees on anthracite mine-spoil areas. USDA, Forest Serv. Res. Pap. NE-22.

5. BARR, J. 1969. Derelict Britain. Penguin Books. 240 p.

6. THIRGOOD, J. V. 1970. The planned reclamation of mined lands. West. Miner 43 (6): 22-25.

\title{
Progress in reclamation research in British Columbia during 1970
}

\section{J. V. THIRGOOD and J. R. MATTHEWS}

University of British Columbia

Faculty of Forestry

Vancouver 8, B.C.

Les progrès dans la recherche sur la restauration en Colombie Britannique en 1970. En 1969, le gouvernement de Colombie britannique a introduit dans la législation des articles spéciaux pour la restauration des terrains miniers à ciel ouvert. Les progrès accomplis à la lumière de cette législation sont passés en revue et des suggestions sont faites pour la conduite plus rationnelle du programme de recherche et de développement nécessaire.

There are implications for foresters in the provisions for the reclamation of surface mined lands, introduced by the provincial government of British
Columbia in 1969. This legislation (1) requires the filing of a Reclamation Plan by the mining company, but prior to final acceptance investigations must be made over a period of three years or longer to determine the methods to be employed to reclaim the disturbed land (2). In the methodologies now being developed the establishment of a tree cover will have a major role.

The purpose here is to review progress during the first year of the legislation. This paper is based on 
an examination of the 15 company reports of work done during 1970 that had been submitted to the Department of Mines and Petroleum Resources by February 1971 and which are available for public examination.

Generally most reports deal with trials set up to assess the value of various species for use in reclamation and, to an extent, methods of establishment. Few mention field scale reclamation in progress and those that do generally view these as being of the nature of field trials. In one instance an area of 880 acres was seeded and 75 acres planted. Each technique will now be examined separately.

\section{Grass and forb plots}

The usual procedure was to establish plots representative of areas to be reclaimed and to sow these with various mixtures of grasses, legumes and other forbs, usually in comparative trials. In only few instances were results presented in these initial reports. In some instances the effects of fertilization and irrigation were examined. Two companies had obtained hydroseeders and were trying these on a field scale. One of these companies had also used a helicopter to seed 180 acres to grass. Plots have been established on broken rock, overburden, waste coal, tailings and dam faces, on derelict industrial sites, deep mine dumps, cleared town-sites, road cuts and fills and on disturbed natural surfaces. One of the two companies mentioned above has assessed the value of peat moss and wood pulp for mulching. The other, not yet in production, conducted growth chamber experiments on simulated spoil materials obtained by crushing drill core samples obtained from the areas to be mined.

\section{Tree plots}

Generally a similar pattern to the grass and forb plots was adopted but on a smaller scale. Some companies did not envisage the use of trees at all and some of those that did saw trees in a combined role with grass and forbs. It must be pointed out that several companies, although they do not mention it in their reports, hope to create large open areas, after reclamation, which will provide range for local game populations. In two cases, comparative species trials have been laid out. In a few instances a range of fertilizers was tested. Usual practice, however, was to plant between 1,000 and 3,000 trees to "see how they fared".

\section{Species selection}

There was no reported use of exotic tree species or of the standard reclamation species used in other parts of the world. In most instances locally available plants were used. Three companies obtained planting stock from origins selected to suit local conditions. Two of these reported that they had collected their own seed for subsequent years. One of them has selected seed trees for future collec- tions. This company has established a forest nursery and greenhouse with seed storage facilities and is currently growing its own planting stock, including introduced species.

\section{Planting techniques}

Two companies stated that they were testing different planting procedures. One was experimenting with the technique of bullet planting.

\section{Landscaping}

This is an all-embracing term to cover work done in beautifying the mine areas. One company has prepared a landscape plan to reclaim the site of an old mining town and had demolished and cleared many of the old structures. Other work of a landscape nature that was done during 1970 was grading of overburden so that it conformed with the general topography, the planting and turfing of mine approach areas, the burning and clearing of an old mine concentrator, the retaining of trees and other vegetation unless absolutely essential that these be cleared, the construction of an observation post for mine visitors, and, on one occasion, the planting of ornamental trees.

\section{Soil testing and slope stability}

Soil testing was not a common procedure among the companies and varied from a cursory examination to a complete laboratory analysis. Engineering consultants were retained on two occasions to check the stability of tailings, dam walls and waste dump slopes. Rock material was used in one case to check erosion occurring on a dam face. Another company had trucked in topsoil to the area around the mine office and had subsequently seeded this to grass. On several occasions it was noted that topsoil was being stockpiled for future reclamation work.

\section{Climate}

Only two companies made any reference to the collection of local climatic information. Both have established their own weather stations.

\section{Water quality}

Little mention is made in the reports regarding control of water quality. Most companies have emphasized the revegetating aspect of reclamation work. In three instances the British Columbia Research Council had been retained to monitor water quality.

The only other company to mention the topic states that they are monitoring all streams for turbidity, $\mathrm{pH}$ and heavy metal ion concentration. All other references to water relate to the relocation of water courses, an area under the jurisdiction of the Comptroller of Water Rights. 


\section{Supervision and advice}

Eight of the fifteen firms had made use of a professionally qualified firm or individual, usually these were qualified in a renewable resource management or related field. Three companies had retained the British Columbia Research Council to make a comprehensive pre-mining ecological survey that embraced all environmental factors. Usually, however, companies have employed a specialist either on a full time or consultant basis to suggest suitable investigations; frequently he implemented these proposals.

\section{Conclusions}

It is hardly valid to criticize progress during this initial year. Certainly there were instances when tree species have been planted outside their range and cases where seeding and planting operations had been carried out with nice diregard for season. In many instances there has also been scant regard for provenance except by chance. There were also some examples of what can perhaps fairly be termed tokenism. One instance is reported where of 100 trees planted just outside the mine office during summer 93 died of drought! But it is hardly just to criticize mine managers for an initial lack of understanding of what to many is a quite unknown field. Mining engineers are primarily concerned with the movement and concentration of large masses of inert material and their organizations are directed toward that end. This is a far cry from the approaches necessary in handling the plasticity of biological material. Certainly in almost every instance the Reclamation Proposals that have been submitted are impressive in their stated intent and careful preparation.

Clearly any attempt to bring reclamation into the mining laws of the province should be applauded as a move in the right direction and, as Hogg (3) has stated, the provisions of the legislation appear sound. Nonetheless there are certain deficiencies. Firstly the legislation does not cover underground mining $^{1}$, and waste dumps that result from such activities are outside the scope of present reclamation provisions. Secondly there is no provision for the restoration of land disturbed during exploration activities $^{2}$. Lastly, the various effects of mining are still not under the administration of one body. While

\footnotetext{
${ }^{1}$ Subsequently underground mining has been brought within the scope of the legislation.

${ }^{2}$ In summer 1971 retrospective regulations were introduced to require reclamation of exploration roads and trial workings in the case of coal mining; hard rock or metallic mining exploration activities still remain outside the scope of the regulations.
}

the mining legislation provides for the protection of water courses, the changing of direction of a water course is under the jurisdiction of the Comptroller of Water Rights and the discharge of wastes into a waterbody is under the licence of the Pollution Control Board, while matters of fisheries concern are the responsibility of the Provincial Fish and Wildlife Branch and the Federal Government.

The issuance of permits to clear land prior to mining is under the jurisdiction of the British Columbia Forest Service but on forest land revegetation is under the control of the Inspector of Mines, while mining operations in Parks require a special use permit from the Parks Branch.

However, these are minor criticisms. To an extent they can be taken care of through interdepartmental co-operation, though the Reclamation Section of the Mines Inspectorate is almost certainly understaffed for the work that it has to do. Of more major import is the dissipation of research effort. As of January 1971 thirty-two permits have been issued and each company is engaged in reclamation studies of some kind. These are uncoordinated and there is considerable duplication. While mining is responsible for the production of $5.4 \%$ of the gross provincial product and mineral goods exclusive of processing comprise $26 \%$ of exports, the total area currently disturbed by mining in the Province is only 76 square miles out of 365,000 square miles. Nevertheless, surface mining operations have significantly greater evironmental impact than is indicated by the area covered by the actual operations. In the absence of developed reclamation techniques major research activity is essential. Surely the obvious solution is for the establishment of a provincial research agency, possibly under the aegis of one of the Provincial resource departments or the University, funded by the government and/or the mining companies. This would eliminate duplication, misdirected effort and hopefully bring a little more rationale into the research being conducted. Currently the only action in this direction is the research program being undertaken in the Faculty of Forestry, University of British Columbia, in which currently five graduate students and two undergraduates are engaged in thesis research projects and in which a Province-wide view is taken.

\section{References}

1. COAL MINES REGULATION ACT: STATUTES OF BRITISH COLUMBIA. 1969. Chap. 3, sect. 8 / MINES REGULATION ACT: STATUTES OF BRITISH COLUMBIA. 1967. Chap. 25. / 1969. Chap. 18, sect. 11.

2. THIRGOOD, J. V. 1970. The planned reclamation of mined lands. West. Miner. 43 (6): 22-25.

3. HOGG, J. L. E. 1971. Mined-land reclamation in British Columbia. The importance of institutional and environmental factors in the formulation of policy. Forest. Chron. 47: $x x x-x x$. 